\title{
Seroprevalence of viral hepatitis A, B, C, D and $E$ viruses in the Hormozgan province southern Iran
}

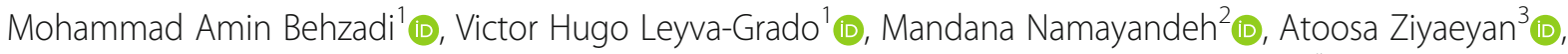 \\ Roya Feyznezhad ${ }^{4} \mathbb{D}$, Hedayat Dorzaban ${ }^{5} \mathbb{D}$, Marzieh Jamalidoust ${ }^{2}$ (D) and Mazyar Ziyaeyan ${ }^{2^{*}}$ (B)
}

\begin{abstract}
Background: Viral hepatitis is a global public health problem affecting millions of people worldwide, causing thousands of deaths due to acute and persistent infection, cirrhosis, and liver cancer. Providing updated serologic data can improve both surveillance and disease control programs. This study is aimed to determine the seroprevalence of markers for viral hepatitis (A, B, C, D and E) and the epidemiology of such infections in the general population of southern Iran's Hormozgan province.

Methods: Between 2016 and 2017, a total of 562 individuals with ages ranging from 1 to 86 years, who visited governmental public laboratories for routine check-ups, were tested for the presence of serological markers to hepatitis virus types A to E using enzyme-linked immunosorbent assays.

Results: The overall anti-hepatitis A virus (HAV) antibody seroprevalence was 93.2\% (524/562). The prevalence of anti-hepatitis E virus (HEV) antibodies was 15.8\% (89/562) among which 1.6\% (9/562) of the seropositive individuals also had evidence of recent exposure to the virus (IgM positivity). Two and a half percent (14/562) were positive for hepatitis B surface (HBs) antigen, whereas 11.6\% (65/562) tested positive for anti-hepatitis B core (HBC) antibodies. Among anti-HBc positive patients, 11\% (7/65) had HBs Ag and 5\% (3/65) were positive for anti-hepatitis D virus (HDV) antibodies. The prevalence of anti-hepatitis $\mathrm{C}$ virus ( $\mathrm{HCV}$ ) antibodies was $0.7 \%$ (4/562). The seroprevalence of anti-HAV, HEV IgG, anti-HBC antibodies, and HBs Ag increased with age.

Conclusion: The present study confirms a high seroprevalence of HAV infection among the examined population and reveals high levels of endemicity for HEV in the region. Planned vaccination policies against HAV should be considered in all parts of Iran. In addition, improvements on public sanitation and hygiene management of drinking water sources for the studied area are recommended.
\end{abstract}

Keywords: Viral hepatitis, Epidemiology, Seroprevalence, General population, Cross-sectional study, Southern Iran

\section{Background}

Hepatitis viruses are circulating worldwide, but their distribution patterns are different in every individual country. Despite the existence of effective vaccines against hepatitis $A$ and $B$, viral hepatitis is still a major global public health concern $[1,2]$. Due to the abundance of asymptomatic or unreported cases, prevalence of such diseases is underestimated even under the best surveillance systems. Therefore,

\footnotetext{
* Correspondence: ziyaeyanm@sums.ac.ir

2Department of Clinical Virology, Clinical Microbiology Research Center,

Shiraz University of Medical Sciences, Namazi Hospital, Shiraz, Iran

Full list of author information is available at the end of the article
}

epidemiological studies in different geographical regions and among different population groups seem to be necessary to reveal the real prevalence and to estimate their true burden. Such data can help to develop appropriate prevention, vaccination and treatment programs.

Hepatitis A virus (HAV) is reported as an important cause of acute viral hepatitis, and associated with socioeconomic losses and a significant cause of morbidity in certain areas of the world [3]. Transmission of the virus is through the fecal-oral route and mainly related to poor sanitation and consumption of contaminated water and food [2]. HAV infection is usually asymptomatic

(c) The Author(s). 2019 Open Access This article is distributed under the terms of the Creative Commons Attribution 4.0 International License (http://creativecommons.org/licenses/by/4.0/), which permits unrestricted use, distribution, and reproduction in any medium, provided you give appropriate credit to the original author(s) and the source, provide a link to the Creative Commons license, and indicate if changes were made. The Creative Commons Public Domain Dedication waiver (http://creativecommons.org/publicdomain/zero/1.0/) applies to the data made available in this article, unless otherwise stated. 
during early life but severity of infection rises with increasing age. Although the infection is usually self-limited, the fatality rate varies from 0.01 to $1 \%$ in adults [3]. In a cross-sectional survey in southern Iran, HAV infection was found to be endemic in the region with an estimated antiHAV seroprevalence of $67.7 \%$ [4]. The results of a systematic review and pooled analysis similarly revealed that $62.24 \%$ of Iranians are HAV seropositive [5]. Currently, there is no nationwide HAV vaccination in Iran.

Hepatitis E virus (HEV) similar to HAV is mainly transmitted via the fecal-oral route especially through contaminated water and it is associated with large water-borne outbreaks. Although HAV and HEV transmission routes are similar, their epidemiology is substantially different. HEV can also be transmitted parenterally by blood transfusion or direct contact with infected animals [6-8]. The infection is self-limiting with mortality rate of about 1 to $2 \%$ in the general population. However, the mortality rate can increase up to $45 \%$ in high risk populations such as pregnant women [9]. In Immunodeficient or immunocompromised patients HEV infection may result in chronic infections. A meta-analysis study among Iranians reported an HEV seroprevalence of about 10\% [10]. However, this prevalence increased up to $25.5 \%$ in high density populated areas of metropolitan cities of Iran [11].

Hepatitis B virus (HBV) and hepatitis C virus (HCV) infections are the major risk factors for the development of chronic hepatitis, cirrhosis, and hepatocellular carcinoma. It is estimated that 350 and 200 million people around the world are chronically infected with HBV and HCV, respectively. The routes of transmission for both HBV and $\mathrm{HCV}$ are the same and include exposure to contaminated blood or other body fluids during injection of drugs, sexual contact, or mother-to-child transmission during the perinatal period. In Iran, the prevalence of HBV infection is about $2.2 \%$ among the general population [12]. In contrast to $\mathrm{HAV}$, Iran has a nationwide $\mathrm{HBV}$ vaccination program. In a recently published meta-analysis study based on the data of 340 published papers, anti-HCV IgG was found in $0.3 \%$ of low risk population consisting of blood donors, pregnant women, children, and adults; in $6.2 \%$ of intermediate risk population including healthcare workers, household contacts of HCV infected patients, female sex workers, prisoners, and homeless individuals; in $32.1 \%$ of high risk population such as HIV-infected patients, hemodialysis patients, hemophilia patients, thalassemia patients; and in $4.6 \%$ among individuals under specific clinical conditions affecting the liver such as chronic liver disease, acute viral hepatitis, hepatocellular carcinoma, and liver cirrhosis [13].

Most epidemiological studies on viral hepatitis have been limited to groups with different risk factors, like hemodialysis patients, HIV positive individuals, etc., therefore, limited local and nationwide data is available in the general population. The aim of the present study is to determine the current seroprevalence of HAV, HBV, HCV, $\mathrm{HDV}, \mathrm{HEV}$ as well as the epidemiological factors involved in the presence of the infection in the general population of the Hormozgan province in southern Iran.

\section{Methods}

\section{Study design and sample collection}

In across-sectional study, we analyzed leftover serum samples collected from individuals who attended major referral governmental public laboratories and units of health located in four major counties (Khamir, Bandar Abbas, Bashagard and Jask) of the Hormozgan province. Hormozgan is located on the northern shore of the Persian Gulf with a total population of 1,776,415 (Central statistics agency report, 2016, Fig. 1) and most of the provincial population are settled in these four studied counties. Therefore, the results of all types of population-based studies in these areas can be expanded to the entire province. This study was conducted with samples obtained from patients that used the laboratory services for reasons such as routine check-ups, obtaining of health certificates or follow ups of their non-infectious chronic diseases, during the period of 2016-2017. Before sample collection a verbal consent was obtained from all the volunteers. Since the seroprevalence average of viral hepatitis viruses in Iran varies between 2 to $62 \%$ for $\mathrm{HCV}$ and HAV, respectively, to reduce the sample size bias, we used the average prevalence of HEV (10\%) as a conservative sample proportion. Using a single population proportion formula, a minimum sample size was estimated 138 based on the following assumptions: $95 \%$ confidence interval $\left(Z_{\alpha / 2}=1.96\right), 10 \%$ proportion $(\mathrm{P})$, and $5 \%$ margin of error $(\mathrm{d})$.

$$
n=\frac{\left(Z_{\alpha / 2}\right)^{2} \times P(1-P)}{d^{2}}
$$

Socio-demographic data including age, gender, residential area, skin type or complexion, and employment status were collected from the participants. The skin complexion was identified using the Fitzpatrick skin type scale that identified six different numerical classification schemes for human skin color, as previously described $[14,15]$. Skin complexion was categorized into three groups; type I/II, type III/IV, and type V/VI. In this area most people with outdoor jobs tend to consume more street food and water, increasing the potential risk of exposure to food contaminated with HAV and HEV. Since they also have high level of skin exposure to the sun resulting in sun tan, we collected the skin type data as an indirect indicator for potential exposure to contaminated food in our statistical model. To minimize the bias of the study, samples of individuals with medical history 


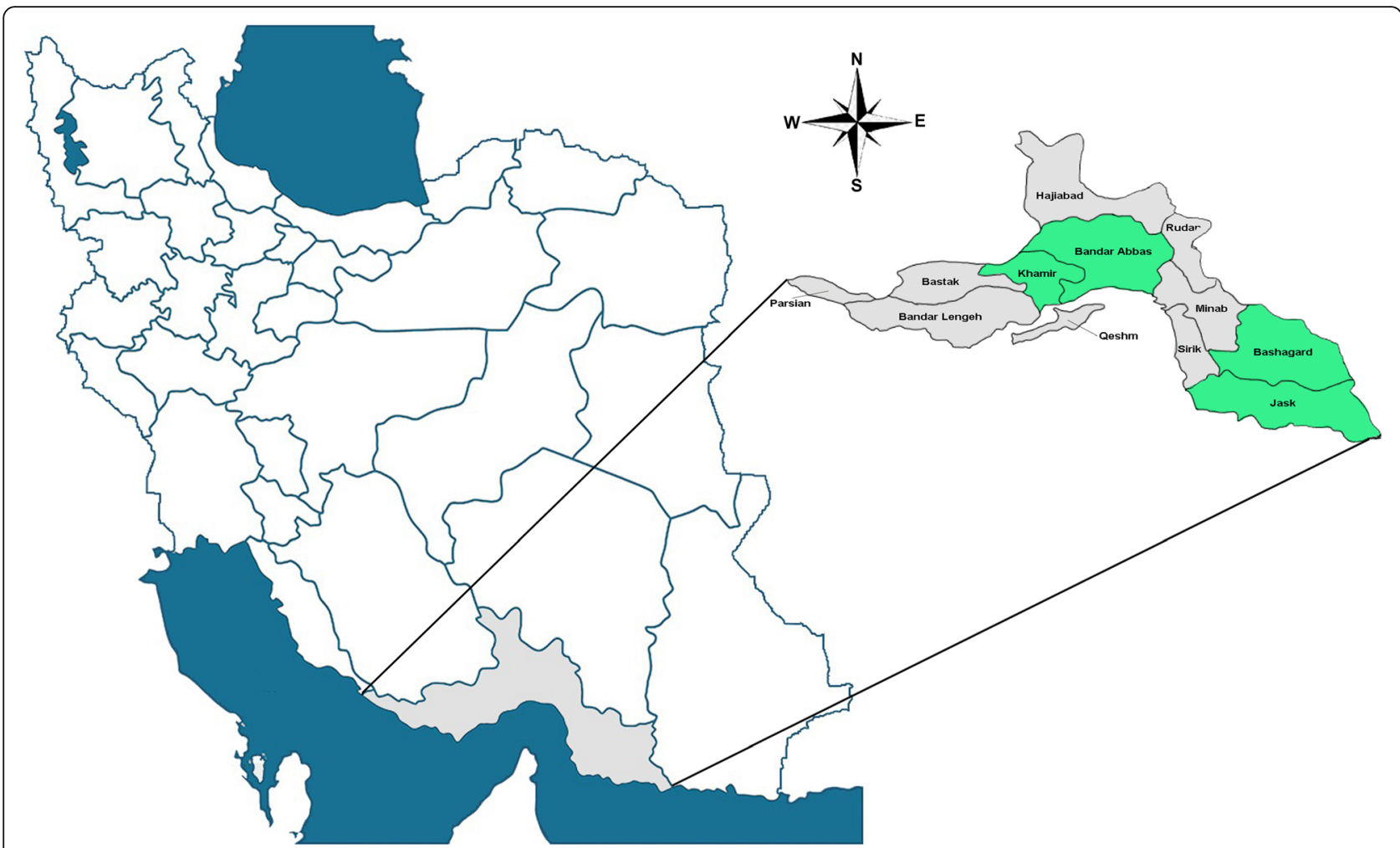

Fig. 1 Map of Iran and Hormozgan province with location of the study counties; Bandar Abbas, Khamir, Jask and Bashagard. The sampling areas are highlighted in green

of immunological disorders including patients that were on chemotherapy or immunosuppressive treatments were excluded. Serum samples were allocated numbers and stored at $-70 \mathrm{C}$ until tested at the department of clinical virology, Clinical Microbiology Research Center, Shiraz University of Medical Sciences, Shiraz, Iran.

\section{Ethical considerations}

The study protocol was approved by the ethics board of the Clinical Microbiology Research Center, Shiraz University of Medical Sciences. The committee waived the need for written informed consent from the study participants for collection of leftover sera.

\section{Laboratory tests for hepatitis seroprevalence}

Patients' sera were tested for the following viral markers using seven commercial enzyme immunoassay kits (Dia. Pro Diagnostic BioProbessrl, Milan, Italy) according to the manufacturer's instructions: total antibodies to HAV, IgGs and IgMs to HEV, hepatitis B surface antigen (HBs $\mathrm{Ag}$ ), antibodies to hepatitis $\mathrm{B}$ core antigen ( $\mathrm{HBc} \mathrm{Ab})$, and antibodies to HCV. Positive samples for $\mathrm{HBs} \mathrm{Ag}$ and/or $\mathrm{HBc} \mathrm{Ab}$ were evaluated for antibodies to HDV. The samples found to be located in the equivocal results (gray zone), were re-tested and if ranged again in the gray zone, they were considered as positive results.

\section{HBV DNA detection and genotyping}

Viral DNA was extracted from $\mathrm{HBs} \mathrm{Ag}$ and/or $\mathrm{HBc} \mathrm{Ab}$ reactive samples and subsequently tested for HBV DNA by quantitative real-time PCR assay, as previously described [16]. Samples with HBV-DNAemia were subjected to HBV genotyping test as described previously [17]. All quantitative reactions were performed in a StepOne Plus Real-time PCR System instrument (Applied Biosystems, USA).

\section{HCV RNA detection and genotyping}

All positive serum samples for anti-HCV antibodies were analyzed for HCV RNA and genotyping. The HCV RNA was extracted and measured by a single tube quantitative rt-real-time PCR. The test conditions for detection of HCV RNA were as previously described [18]. HCV genotyping was done on HCV RNA positive samples as previously described [19]. All reactions were performed in a StepOne Plus Real-time PCR System instrument (Applied Biosystems, USA).

\section{Statistical analysis}

All data analyses were performed using SPSS statistical software version 22 (IBM Corp, New York, USA), and a $p$ value of less than 0.05 was considered statistically significant. Initially, seven separate univariate logistic regression 
models were created to examine the correlation of various demographic factors with the presence of total antibodies to HAV, IgM and IgG antibodies to HEV, antibodies against $\mathrm{HBc} \mathrm{Ag}$, presence of $\mathrm{HBS} \mathrm{Ag}$, and antibodies to HCV. All risk factors or confounders with statistically significant association in univariate analysis were entered in their separated multiple logistic regression models. Odds ratios and 95\% CIs were calculated.

\section{Results}

In a period of 16 months from January 2016 to April 2017, 562 volunteers were enrolled in this study. The participants' socio-demographic characteristics are summarized in Table 1 . The age range was between 1 and 86 years (mean \pm SD: $35.74 \pm 17.06$ y). To achieve reliable statistical analysis the studied participants were reclassified into three age groups (1-25, 26-45, and 45+) and seven occupation categories (child/student, house wife, office employee, freelancer, fisherman/sailor, worker and retiree). The occupational groups were further allocated into three major categories based on where they performed their activities: mostly indoor, usually indoor and mostly outdoor.

\section{Hepatitis A}

The overall seroprevalence of HAV antibodies was 93.2\% (524/562). The results of univariate logistic regression analysis show that HAV prevalence is significantly associated with increasing age (45+ and $26-45$ vs. $1-25$; $\mathrm{OR}=11.423,95 \% \mathrm{CI}: 3.422-38.135$ and $\mathrm{OR}=17.551$, 95\% CI: 5.277-58.376, respectively), and skin type (type III/IV vs. type I/II; OR $=2.801,95 \%$ CI: $1.394-5.627$ ). The seropositivity rate for anti-HAV in Bandar Abbas county significantly decreased to $88.1 \%$ in comparison to the other three counties $(p=0.049)$. No significant differences were observed in the anti-HAV seroprevalence between male and female, rural and urban, and occupation categories. After the multivariable logistic regression analysis, the difference in prevalence of anti HAV antibodies between different skin type and residential area was no longer significant. In the following step, removing the skin type variable from the logistic regression model resulted again in a significant association of residential area and HAV seropositivity. A strong association between increasing age and HAV seroprevalence ( $45+$ and $26-45$ vs. $1-25$; OR $=12.433,95 \%$ CI: $3.642-$ 42.445 and $\mathrm{OR}=17.762,95 \% \mathrm{CI}: 5.297-59.560$, respectively) was observed. Factors associated with HAV infection among subject people on univariate analysis and multivariate analysis are summarized in Table 2.

\section{Hepatitis E}

The positivity rates for anti-HEV IgG and IgM among the participants was $89 / 562(15.8 \%)$ and 9/562 (1.6\%),
Table 1 Study populations' demographic characteristics

\begin{tabular}{|c|c|c|c|}
\hline Characteristic & Group & Total count $(n=562)$ & Percent (\%) \\
\hline \multirow[t]{6}{*}{ Age (years) } & $0-14$ & 30 & 5.3 \\
\hline & $15-24$ & 118 & 21.0 \\
\hline & $25-34$ & 169 & 30.1 \\
\hline & $35-44$ & 84 & 14.9 \\
\hline & $45-54$ & 69 & 12.3 \\
\hline & $55+$ & 92 & 16.4 \\
\hline \multirow[t]{2}{*}{ Gender } & Female & 398 & 70.8 \\
\hline & Male & 164 & 29.2 \\
\hline \multirow[t]{4}{*}{ Residential area } & Bandar Khamir & 140 & 24.9 \\
\hline & Jask & 137 & 24.4 \\
\hline & Bandar Abbas & 143 & 25.4 \\
\hline & Bashagard & 142 & 25.3 \\
\hline \multirow[t]{2}{*}{ Resident type } & Urban & 283 & 50.4 \\
\hline & Rural & 279 & 49.6 \\
\hline \multirow[t]{3}{*}{ Skin type } & Type I/II & 116 & 20.6 \\
\hline & Type III/IV & 417 & 74.2 \\
\hline & Type VNI & 29 & 5.2 \\
\hline \multirow[t]{7}{*}{ Occupation } & Child/student & 77 & 13.7 \\
\hline & House wife & 318 & 56.6 \\
\hline & Office employee & 56 & 10.0 \\
\hline & Freelancer & 52 & 9.3 \\
\hline & Fisherman/Sailor & 20 & 3.6 \\
\hline & Worker & 27 & 4.8 \\
\hline & Retiree & 12 & 2.1 \\
\hline \multirow[t]{2}{*}{ Travelling history } & No & 519 & 92.3 \\
\hline & Yes & 43 & 7.7 \\
\hline
\end{tabular}

respectively. As expected, the majority of IgG positivity was observed in $45+$ age group, and for IgM positivity in youngest age group (1-25 y).In univariate analysis HEV prevalence was associated with age (45+ vs. $1-25$; OR = 2.384, 95\% CI: 1.298-4.377), residential area (Bandar Abbas vs. Jask; OR $=2.251,95 \%$ CI: $1.155-4.389$ ) and occupation (occupation group 3 vs. occupation group 1; $\mathrm{OR}=2.252$, 95\% CI: 1.188-4.271). Bandar Abbas residents were more likely to have HEV IgG than other parts of Hormozgan in the multivariate analysis. The logistic regression model also showed the association of increasing age and anti-HEV seropositivity (45+ vs. 125; $\mathrm{OR}=2.193,95 \% \mathrm{CI}: 1.174-4.094)$. The results for HEV IgG and IgM serology are summarized in Table 3 and Additional file 1: Table S1.

\section{Hepatitis B and D}

Anti-HBc antibodies and $\mathrm{HBs} \mathrm{Ag}$ were detected in $65(11.6 \%)$ and $14(2.5 \%)$ individuals, respectively. The prevalence of anti-HBc antibodies and $\mathrm{HBs} \mathrm{Ag}$ increased 


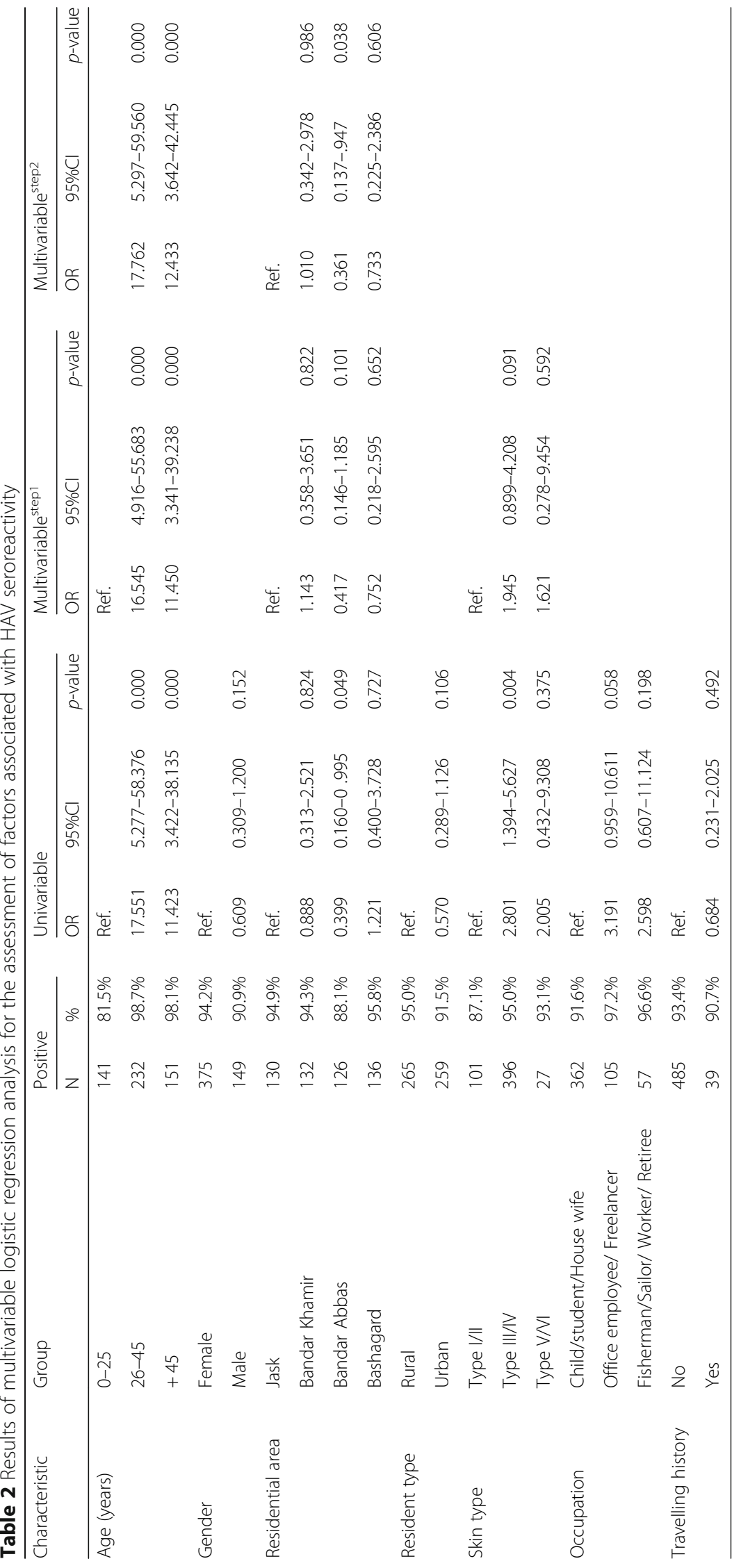




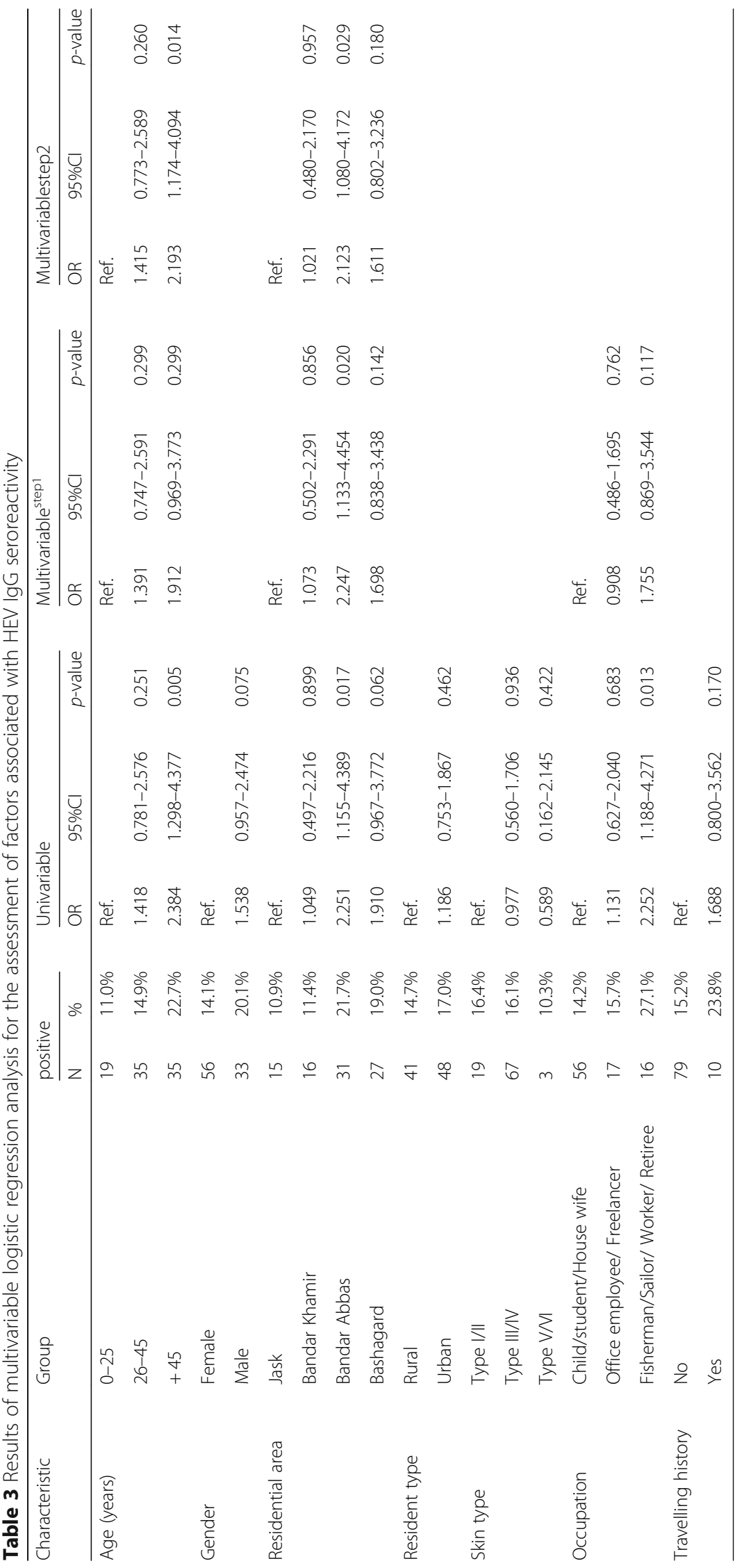


proportionally with age. People over 45 years old had significantly higher levels of $\mathrm{HBC}$ antibodies and $\mathrm{HBs} \mathrm{Ag}$ than those who were younger $(\mathrm{OR}=4.970,95 \% \mathrm{CI}$ : 2.293-10.772 and OR $=8.190,95 \%$ CI: $0.996-67.343$ respectively). The highest number of anti-HBc positive patients were observed in Bandar Abbas county (18.9\%) and the lowest was recorded among people living in Jask county with $7.3 \%$ seropositivity (Bandar Abbas vs. Jask; $\mathrm{OR}=2.956,95 \% \mathrm{CI}: 1.371-6.371)$. Univariable analysis indicated a significant impact of office employment and freelancer on the anti-HBc and HBs Ag positivity test results. However, multivariable analysis did not confirm it $(\mathrm{OR}=2.338,95 \%$ CI: $1.287-4.246$ vs. $\mathrm{OR}=1.544,95 \% \mathrm{CI}$ $0.813-2.930$ and $\mathrm{OR}=3.261,95 \% \mathrm{CI}: 1.072-9.914$ vs. $\mathrm{OR}=2.320,95 \%$ CI: 0.743-7.242, respectively) (Table 4, and Additional file 2: Table S2). In addition, among HBc antibodies positive patients, $7(11 \%)$ were positive for $\mathrm{HBs} \mathrm{Ag}$ and 3(5\%) were positive for anti-HDV antibodies. Anti-HDV positivity was accompanied by the presence of $\mathrm{HBs} \mathrm{Ag}$ in 1 individual. The rest of $\mathrm{HBs} \mathrm{Ag}$ positive patients were negative for anti-HDV antibodies. All $58 \mathrm{HBc}$ antibodies positive and $\mathrm{HBs} \mathrm{Ag}$ non-reactive patients were negative for HBV DNA. Among 14 subjects who were $\mathrm{HBs} \mathrm{Ag}$-positive, 11 patients showed detectable HBV DNA levels ranging from 1200 to 175,800 copies/mL of plasma. HBV genotype D was found in 7 subjects with detectable HBV DNA.

\section{Hepatitis C}

HCV antibodies were present in $0.7 \%(4 / 562)$ of all participants. The HCV RNA was detected in $2 \mathrm{HCV}$ antibody positive patients with 7300 and 4500 HVC RNA copy numbers per $\mathrm{ml}$ of plasma and genotypes $1 \mathrm{a}$ and $3 \mathrm{a}$, respectively. $\mathrm{HBc}$ antibodies were observed in $1 \mathrm{HCV}$ $\mathrm{Ab}$ positive patient. The results of $\mathrm{HCV}$ seroprevalence are summarized in Additional file 3: Table S3.

\section{Discussion}

In the present study seroprevalence of various viral hepatitis infections from $\mathrm{A}$ to $\mathrm{E}$ have been determined in four major counties (Khamir, Bandar Abbas, Bashagard, and Jask) of the Hormozgan province in southern Iran from 2016 to 2017 (Fig. 2). The results revealed a high level of HAV in the studied population. This suggests a common source of infection such as contaminated water supply system due to the lack of proper disposal system or contaminated source of drinking water. Possible source of contamination of water with HAV in this region may be related to untreated sewage of human. The overall prevalence of HAV infection was $93.2 \%$, with the lowest frequency in Bandar Abbas (88.1\%) and the highest in Bashagard (95.8\%) counties. The reason for such difference may be related to better standards of sanitation in larger cities such as Bandar Abbas which is the province's capital. In this region of the country, the sewage is almost always properly treated in urban areas, while in the rural parts, human waste is usually gathered in underground tanks and accidental overflows may end up in lagoons and rivers around them. These waters are the main source of agriculture irrigation and if contaminated they are also a source of infection for the human population. Consistent with previous reports [5], our results show that the prevalence of HAV Ab increases with age, suggesting the cumulative exposure to HAV with time. In other countries of the Eastern Mediterranean Region, high seroprevalence of HAV has been previously reported. In Afghanistan (99\%) [20], Iraq (96\%) [21] and Palestine (93.7\%) [22], with the lowest prevalence recorded in UAE and Kuwait with estimated prevalence rate below $50 \%$. The overall HAV seroprevalence in Iran was estimated to be $62 \%$ and can be categorized as intermediate-endemicity for HAV infection [5].

The overall prevalence of anti-HEV IgG was 15.8\% which is higher than Iran's previous studies found in the general population of the Fars province (13.4\%) [4], pregnant women at northern shores of Persian Gulf (6.3\%) [9], and blood donors in Tehran (8.1\%) [23]; but lower than the seroprevalence of HEV infection among adults in Khuzestan province (46.1\%) [24]. The prevalence rate was relatively higher in men $(20.1 \%)$ than in women (14.1\%), but not statistically significant. This finding might be explained by people's lifestyle in the study region, where most men have outdoor jobs while most women stay at home doing housekeeping work. Therefore, men are more exposed to HEV contaminated sources. HEV seropositivity among people who lived in Bandar Abbas area was higher than those resided in the other parts of the province. One problem in big cities like Bandar Abbas is the overcrowding living conditions that many times lead to poor water hygiene. This may contribute to the high level of HEV seropositivity observed in this area. Moreover, the overall prevalence rate of anti-HEV IgM was $1.6 \%$ in our study, giving a low level of recent infection, which is in accordance with previous reports stating $0.5-5 \%$ HEV incidence among healthy individuals [25].

The seropositivity of $\mathrm{HBs} \mathrm{Ag}$ or the rate of current HBV infection was $2.5 \%$. The frequency of anti-HBc antibodies was $11.6 \%$ indicating previous exposure to HBV infection. These findings are in consistent with the average prevalence of $\mathrm{HBs} \mathrm{Ag}(2.2 \%)$ and lower than average prevalence for anti-HBc antibodies (16.4\%) in Iran. A previous study in the same province [26], and also in some of the northern and western provinces of Iran revealed similar results [26-30]. However, the prevalence of anti $\mathrm{HBC}$ antibodies and $\mathrm{HBs} \mathrm{Ag}$ was lower than those of the neighboring province of Sistan and Baluchistan (14.96 and 3.38\%, respectively) [31]. Our 


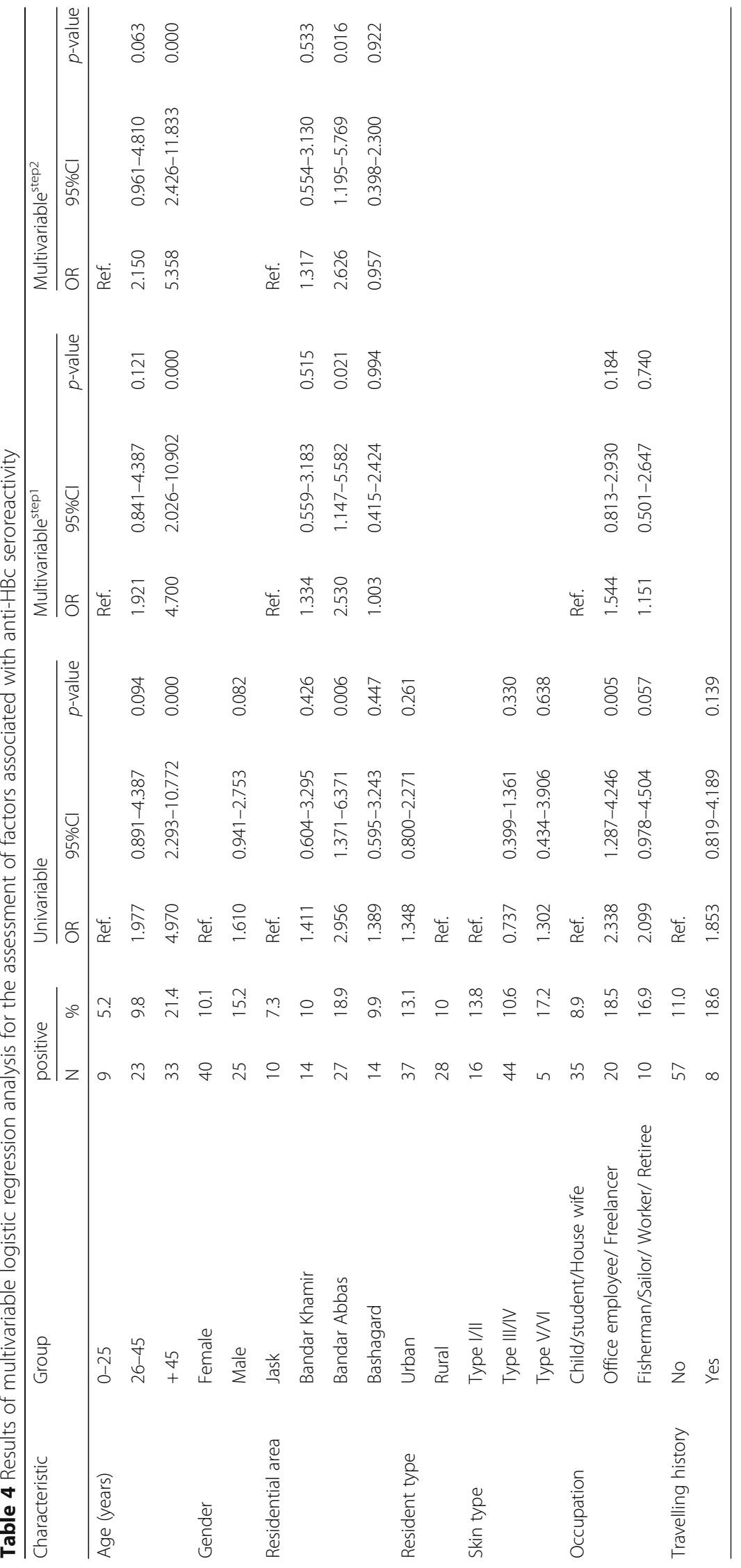




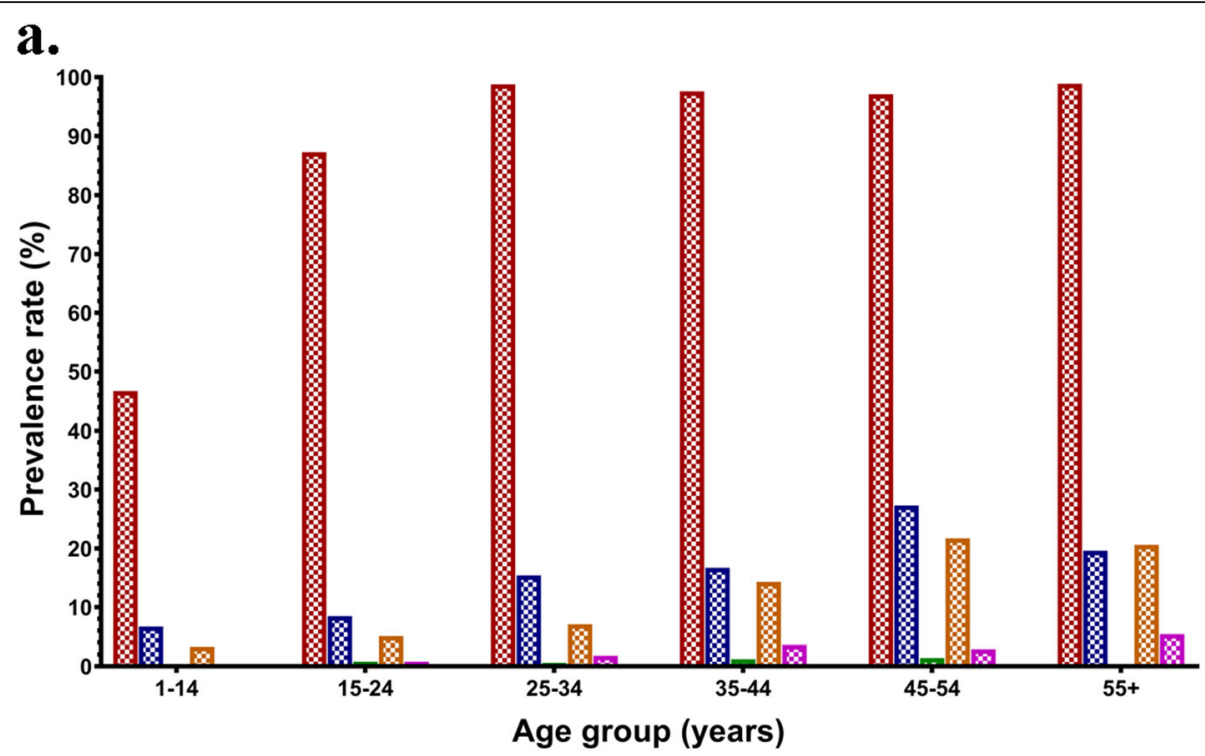

b.
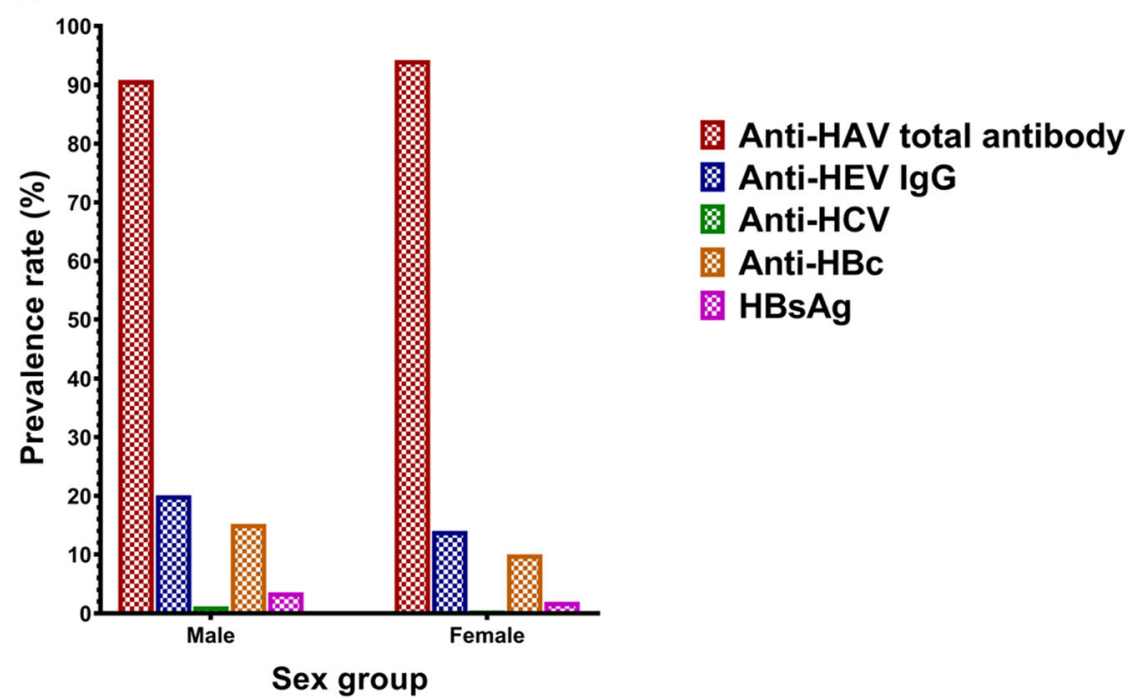

southern Iran (2016-2017)

results show a significant difference in HBV seroprevalence among the studied residential areas. The lowest seroprevalence was observed in Jask, with a more rural and traditional lifestyle, and the highest was in the Bandar Abbas, the largest and most urbanized city in the Hormozgan province. In addition, in our experience, the prevalence of occult $\mathrm{HBV}$ infection in 58 anti-HBc+/HBs Ag- patients was 0\%. Earlier studies on HBV genotyping in Iran determined genotype $\mathrm{D}$ as the prominent type in many parts of the country [32]. Similarly, we also found this genotype among HDV infected patients.

In this study, we observed prevalence of anti-HCV antibodies of $0.7 \%$ which is lower than earlier reports from Kermanshah (0.87\%) [33], Ahvaz (2.3\%) [34], and
Tehran (2.1\%) [35] in Iran. However, it is higher than the results reported by the Kavar cohort study near Shiraz Iran $(0.24 \%)$ [36]. Higher level of $\mathrm{HCV}$ prevalence rates have been reported from Middle East and North Africa countries; Turkey 1.6\%, Saudi Arabia 1.8\%, Pakistan 4.8 and $14.7 \%$ in Egypt [37-40]. Previous studies in Iran showed the most dominant genotype of HCV is 1a followed by 3a [19]. In this study we also observed the same genotypes in two HCV-infected patients.

Our results show that a considerable number of examined individuals had markers for more than one type of viral hepatitis (Fig. 3). The pooled prevalence of $\mathrm{HBV} /$ $\mathrm{HCV}$ co-infection was $0.7 \%$, which is lower than the estimated worldwide prevalence of $1-15 \%$ [41, 42]. Our data 


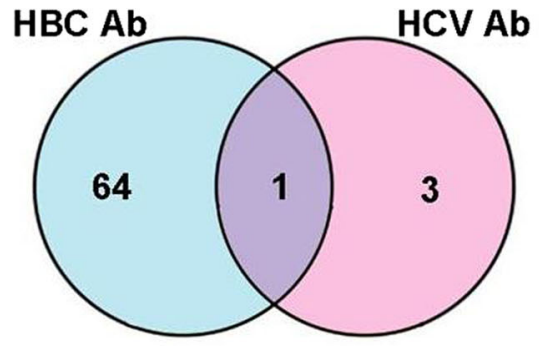

$\mathrm{HBC} \mathrm{Ab}$ HEV Ab
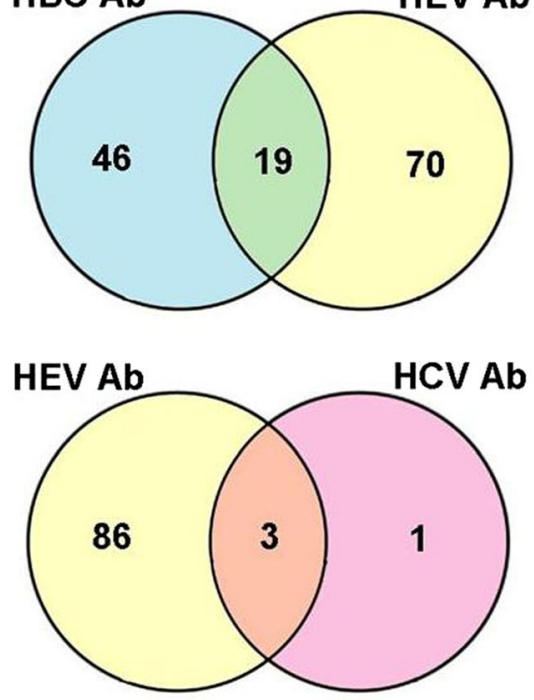

$\mathrm{HCV} \mathrm{Ab}$ HAV Ab

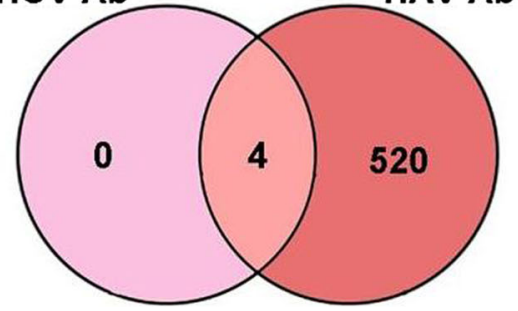

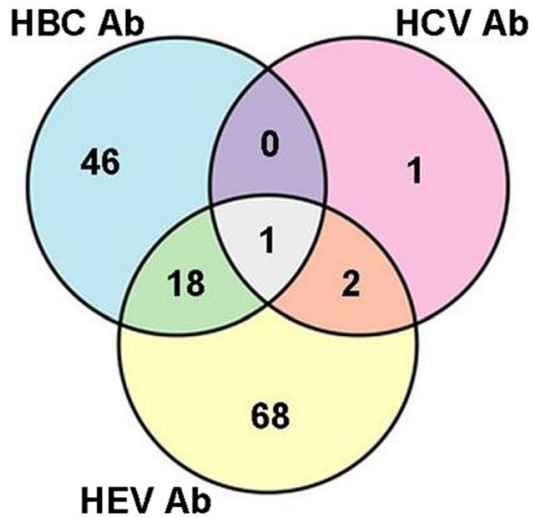

HEV Ab
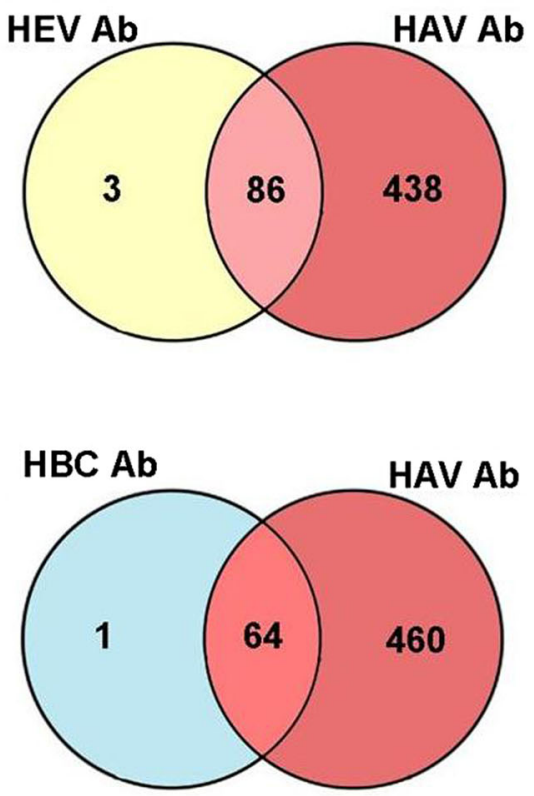

Fig. 3 Hepatitis viruses co-infection markers in Hormozgan province southern Iran (2016-2017, $n=562)$

analysis also revealed the presence of HEV $\mathrm{Ab}$ in one of the $\mathrm{HBV} / \mathrm{HCV}$ co-infected patients; however the route of HEV transmission in this individual was unknown. Previous studies reported rare routes of HEV infection transmission through the blood transfusion or sexual contact in addition to the main fecal-orally route [7, 43].

\section{Conclusion}

In conclusion, our results show a high HAV seroprevalence in southern Iran in comparison with the average prevalence of the country. Since the disease causes vast disease burden, morbidity, occupancy of hospital beds, national economic losses and mortality; prevention strategies are required in Iran. HAV vaccination is the most effective strategy in preventing HAV infection and promising results of vaccination have been observed in different countries such as Taiwan [44] South Korea [45], Israel [46] and USA [47]. Based on their experiences, vaccination should be performed initially in high risk groups like people in orphanages and shelters, women in child bearing ages and children, and then national wide vaccination. Similarly, HAV vaccination should be included in the national vaccination program to achieve a reduction of HAV infection in the general population. At glance, HBV prevalence in Iran during the two to three past decades shows a decreasing trend of the disease. This success is mainly related to the wellorganized anti-HBV national vaccination program among all neonates and infants, as well as, individuals in high risk groups. To achieve a full coverage of the 
general population, the vaccination programs should be extended to all $\mathrm{HBS} \mathrm{Ag} / \mathrm{Ab}$ negative people. Our findings also reveal a considerable high level of HEV prevalence in the region. Since the consumption of contaminated water is the main transmission route of HEV, improving the level of public health sanitation in the area should be considered a priority by policymakers. Although HCV prevalence in the studied population was lower than the world's average, this problem can be further reduced with the use of the novel anti-HCV therapies available in the market.

\section{Supplementary information}

Supplementary information accompanies this paper at https://doi.org/10. 1186/s12879-019-4661-4.

Additional file 1: Table S1. Results of univariable logistic regression analysis for the assessment of factors associated with HEV IgM seroreactivity.

Additional file 2: Table S2. Results of multivariable logistic regression analysis for the assessment of factors associated with HBS Ag seroreactivity.

Additional file 3: Table S3. Results of multivariable logistic regression analysis for the assessment of factors associated with HCV seroreactivity.

\section{Abbreviations}

Cl: Confidence interval; HAV: Hepatitis A virus; HBc: Hepatitis B core; HBs: Hepatitis B surface; HBV: Hepatitis B virus; HCV: Hepatitis C virus; HDV: Hepatitis D virus; HEV: Hepatitis E virus; OR: Odds ratio

\section{Acknowledgements}

We thank the devoted clinical staff of Hormozgan Health Center for their enthusiasm during this project.

\section{Authors' contributions}

MAB contributed to study concept, data search, data extraction and analysis, and drafting of the manuscript; VHLG contributed to data extraction and analysis, critical revision of the manuscript; MN contributed to data extraction and drafting of the manuscript; AZ contributed to data extraction and drafting of the manuscript; RF contributed to data extraction and analysis, and critical revision of the manuscript; HD contributed to data extraction; MJ contributed to data extraction and drafting of the manuscript; $M Z$ contributed to study concept, supervision, revision of the manuscript, guarantor of the article. All authors had full access to the data and gave final approval before submission.

\section{Funding}

This study was supported by the Clinical Microbiology Research Center, Shiraz University of Medical Sciences, Shiraz-Iran. The funding body had no role in the study design, collection, analysis, interpretation of data, and in writing the manuscript.

\section{Availability of data and materials}

The datasets generated and/or analyzed during the current study are not publicly available due to protecting the participants' anonymity but are available from the corresponding author on reasonable request.

\section{Ethics approval and consent to participate}

The study protocol was approved by the ethics committee of the Clinical Microbiology Research Center, Shiraz University of Medical Sciences (no. 2016/950306, dated 26/05/2016). The committee waived the need for written informed consent from the study participants for collection of leftover sera.
Consent for publication

Not Applicable.

\section{Competing interests}

The authors declare that they have no competing interests.

\section{Author details}

${ }^{1}$ Department of Microbiology, Icahn School of Medicine at Mount Sinai, New York, NY, USA. ²Department of Clinical Virology, Clinical Microbiology Research Center, Shiraz University of Medical Sciences, Namazi Hospital, Shiraz, Iran. ${ }^{3}$ Life Science student, Faculty of Arts and Science, University of Toronto, Toronto, Canada. ${ }^{4}$ Division of Infectious Diseases, Department of Medicine, Icahn School of Medicine at Mount Sinai, New York, NY, USA. ${ }^{5}$ Hormozgan Health Center, Hormozgan University of Medical Sciences, Bandar Abbas, Iran.

Received: 25 July 2019 Accepted: 25 November 2019

Published online: 03 December 2019

\section{References}

1. Martin A, Lemon SM. Hepatitis a virus: from discovery to vaccines. Hepatology. 2006;43(S1):S164-72.

2. Thuener J. Hepatitis A and B Infections. Prim Care. 2017:44(4):621-9.

3. Shin E-C, Jeong S-HJ. Natural history, clinical manifestations, and pathogenesis of hepatitis a. Cold Spring Harb Perspect Med. 2018;8(9): a031708.

4. Asaei S, Ziyaeyan M, Moeini M, Jamalidoust M, Behzadi MA. Seroprevalence of hepatitis a and E virus infections among healthy population in Shiraz, Southern Iran. Jundishapur J Microbiol. 2015;8(7):e19311.

5. Safiabadi M, Rezaee-Zavareh MS, Alavian SM. Estimation of hepatitis a virus infection prevalence among eastern Mediterranean and middle eastern countries: a systematic review and pooled analysis. Hepat Mon. 2017;17(2): e44695.

6. Meng X, Wiseman B, Elvinger F, Guenette D, Toth T, Engle R, Emerson S, Purcell RJ. Prevalence of antibodies to hepatitis $E$ virus in veterinarians working with swine and in normal blood donors in the United States and other countries. J Clin Microbiol. 2002:40(1):117-22.

7. Matsubayashi K, Nagaoka Y, Sakata H, Sato S, Fukai K, Kato T, Takahashi K, Mishiro S, Imai M, Takeda N, et al. Transfusion-transmitted hepatitis E caused by apparently indigenous hepatitis E virus strain in Hokkaido, Japan. Transfusion. 2004;44(6):934-40.

8. Tedder RS, Tettmar Kl, Brailsford SR, Said B, Ushiro-Lumb I, Kitchen A, Morgan D, Lattimore S, Tossell J, ljaz S, et al. Virology, serology, and demography of hepatitis E viremic blood donors in South East England. Transfusion. 2016;56(6pt2):1529-36.

9. Farshadpour F, Taherkhani R, Ravanbod MR, Eghbali SS, Taherkhani S, Mahdavi E. Prevalence, risk factors and molecular evaluation of hepatitis $E$ virus infection among pregnant women resident in the northern shores of Persian gulf, Iran. PLoS One. 2018;13(1):e0191090.

10. Niya MHK, Rezaee-Zavareh MS, Ranaei A, Alavian SM. Hepatitis E virus seroprevalence rate among eastern Mediterranean and middle eastern countries; a systematic review and pooled analysis. Microb Pathog. 2017;110:252-6.

11. Ghezeldasht SA, Miri R, Hedayatimoghadam M, Shamsian A, Bidkhori H, Fathimoghadam F, Rezaee SA. Population movement and virus spreading: HEV spreading in a pilgrimage city, Mashhad in Northeast Iran; an example. Hepat Mon. 2013;13(8):e10255.

12. Salehi-Vaziri M, Sadeghi F, Hashiani AA, Fesharaki MG, Alavian SM. Hepatitis $B$ virus infection in the general population of Iran: an updated systematic review and meta-analysis. Hepat Mon. 2016;16(4):e35577.

13. Mahmud S, Akbarzadeh $V$, Abu-Raddad $\sqcup$. The epidemiology of hepatitis $C$ virus in Iran: systematic review and meta-analyses. Sci Rep. 2018;8(1):150.

14. Daniel LC, Heckman CJ, Kloss JD, Manne SL. Comparing alternative methods of measuring skin color and damage. Cancer Causes Control. 2009;20(3):313-21.

15. Pathak MAJ. In memory of Thomas Bernhard Fitzpatrick. J Invest Dermatol. 2004;122(2):xx-xxi.

16. Behzadi MA, Ziyaeyan M, Asaei S. Hepatitis B virus DNA level among the seropositive afghan immigrants, southern Iran. Jundishapur J Microbiol. 2014;7(5):e10127.

17. Naito H, Hayashi S, Abe K. Rapid and specific genotyping system for hepatitis B virus corresponding to six major genotypes by PCR using typespecific primers. J Clin Microbiol. 2001;39(1):362-4. 
18. Behzadi MA, Ziyaeyan M. Hepatitis C virus load in seropositive liver and kidney transplant recipients by quantitative real-time PCR before and after transplantation. Jundishapur J Microbiol. 2013;6(8):e7365.

19. Feyznezhad R, Behzadi MA, Yaghobi R, et al. Determining major genotypes of hepatitis $C$ virus among transplant recipients by real-time polymerase chain reaction assay. Jundishapur J Microbiol. 2015:8(2):e16722.

20. Carmoi T, Safiullah S, Nicand E. Risk of enterically transmitted hepatitis a, hepatitis $\mathrm{E}$, and plasmodium falciparum malaria in Afghanistan. Clin Infect Dis. 2009:48(12):1800

21. Turky AM, Akram W, Al-Naaimi AS, Omer AR, Al-Rawi JR. Analysis of acute viral hepatitis (a and E) in Iraq. Global J Health Sci. 2011;3(1):70.

22. Assin K, Awad R, Tebi A, Queder A, Laaser U. The epidemiology of hepatitis a infection in Palestine: a universal vaccination programme is not yet needed. Epidemiol Infect. 2001;127(2):335-9.

23. Hesamizadeh K, Sharafi H, Keyvani H, Alavian SM, Shabankareh AN-T, Olyaie RS, Keshvari M. Hepatitis A virus and hepatitis E virus seroprevalence among blood donors in Tehran, Iran. Hepat Mon. 2016;16(1):e32215.

24. Farshadpour F, Taherkhani R, Makvandi M. Prevalence of hepatitis E virus among adults in south-west of Iran. Hepat Res Treat. 2015;2015:759589.

25. Wang M, Fu P, Yin Y, He M, Liu Y. Acute, recent and past HEV infection among voluntary blood donors in China: a systematic review and metaanalysis. PLoS One. 2016;11(9):e0161089.

26. Merat S, Rezvan H, Nouraie M, Jamali J, Assari S, Abolghasemi H, Radmard AR, Zaer-Rezaii H, Zeid-Abadi-Nejhad M, Hosseini MR, et al. The prevalence of hepatitis B surface antigen and anti-hepatitis B core antibody in Iran: a population-based study. Arch Iran Med. 2009;12(3):225-31.

27. Fathimoghaddam F, Hedayati-Moghaddam MR, Bidkhori HR, Ahmadi S, Sima HR. The prevalence of hepatitis B antigen-positivity in the general population of Mashhad, Iran. Hepat Mon. 2011;11(5):346-50.

28. Amini S, Mahmoodi MF, Andalibi S, Solati AA. Seroepidemiology of hepatitis B, delta and human immunodeficiency virus infections in Hamadan province, Iran: a population based study. J Trop Med Hyg. 1993;96(5):277-87.

29. Keyvani H, Sohrabi M, Zamani F, Poustchi H, Ashrafi H, Saeedian F, Mooadi M, Motamed N, Ajdarkosh H, Khonsari M. A population based study on hepatitis B virus in northern Iran, Amol. Hepat Mon. 2014;14(8):e20540.

30. Doosti A, Amini-Bavil-Olyaee S, Tajbakhsh E, Adeli A, Mahboudi F. Prevalence of viral hepatitis and molecular analysis of HBV among voluntary blood donors in West Iran. New Microbiol. 2009;32(2):193-8.

31. Salehi M, Alavian S, Tabatabaei S, Izadi S, Moghaddam ES, Kafi-Abad SA, Gharehbaghian A, Khosravi S, Abolghasemi H. Seroepidemiology of HBV infection in south-east of Iran; a population based study. Iran Red Crescent Med J. 2012;14(5):283-8.

32. Haghshenas MR, Arabi M, Mousavi T. Hepatitis B genotypes in Iran. Mater Soc. 2014:26(2):129-33.

33. Sayad B, Shamseddin-Saeed F, Keyvani H, Rezaii M, Asadi T, Vaziri S, Janbakhsh AR, Mansouri F, Afsharian M, Laghaii Z. Seroepidemiology of hepatitis C in Kermanshah (west of Iran, 2006). Hepat Mon. 2008;8(2):141-6.

34. Farshadpour F, Makvandi M, Samarbafzadeh A, Jalalifar MA. Determination of hepatitis C virus genotypes among blood donors in Ahvaz, Iran. Indian J Med Microbiol. 2010;28(1):54-6.

35. Khedmat $H$, Alavian SM, Miri SM, Amini M, Abolghasemi H, Hajibeigi $B$, Alaeddini F, Fallahian F. Trends in seroprevalence of hepatitis B, hepatitis C, HIV, and syphilis infections in Iranian blood donors from 2003 to 2005. Hepat Mon. 2009;9(1):24-8.

36. Fattahi MR, Safarpour A, Sepehrimanesh M, Hosseini Asl SM, Mohamaddoust $F$. The prevalence of hepatitis $C$ virus infection and its related risk factors among the rural population of Fars province, southern Iran. Hepat Mon. 2015;15(2):e24734.

37. Qureshi H, Bile K, Jooma R, Alam S, Afrid H. Prevalence of hepatitis B and C viral infections in Pakistan: findings of a national survey appealing for effective prevention and control measures. East Mediterr Health J. 2010; 16(Suppl):S15-23.

38. Mohamoud YA, Mumtaz GR, Riome S, Miller D, Abu-Raddad LJ. The epidemiology of hepatitis C virus in Egypt: a systematic review and data synthesis. BMC Infect Dis. 2013;13(1):288

39. Çeldir M, Kara I, Coşkuner S, Keskin B, Küçüker M, Orer H, Ergönül O. Hepatitis C prevalence in Turkey: estimation through meta-analysis. Eur J Pub Health. 2014;24:cku163.032.

40. World Health Organization. The growing threats of hepatitis B and C in the Eastern Mediterranean region: a call for action. 2012; Technical Paper EM/RC56/3.
41. Pol S, Haour G, Fontaine H, Dorival C, Petrov-Sanchez V, Bourliere M, Capeau J, Carrieri P, Larrey D, Larsen C, et al. The negative impact of HBV/HCV coinfection on cirrhosis and its consequences. Aliment Pharmacol Ther. 2017:46(11-12):1054-60.

42. Senturk H, Tahan V, Canbakan B, Uraz S, Ulger Y, Ozaras R, Tabak F, Mert A, Ozbay $\mathrm{G}$. Chronic hepatitis $C$ responds poorly to combination therapy in chronic hepatis B carriers. Neth J Med. 2008;66(5):191-5.

43. Amar N, Dalton HR, Abravanel F, Izopet J. Hepatitis E virus infection. Clin Microbiol Rev. 2014;27(1):116-38.

44. Lin JB, Lin DB, Chen SC, Chen PS, Chen WK. Seroepidemiology of hepatitis a, B, C, and E viruses infection among preschool children in Taiwan. J Med Virol. 2006;78(1):18-23

45. Moon S, Han JH, Bae G-R, Cho E, Kim B. Hepatitis a in Korea from 2011 to 2013: current epidemiologic status and regional distribution. J Korean Med Sci. 2016;31(1):67-72.

46. Bassal R, Weil M, Cohen D, Sofer D, Mendelson E, Shohat T. Seroprevalence of hepatitis a twelve years after the implementation of toddlers' vaccination: a population-based study in Israel. Pediatr Infect Dis I. 2017;36(10):e248-51.

47. Murphy TV. Progress toward eliminating hepatitis a disease in the United States. MMWR Suppl. 2016;65(1):29-41.

\section{Publisher's Note}

Springer Nature remains neutral with regard to jurisdictional claims in published maps and institutional affiliations.

\section{Ready to submit your research? Choose BMC and benefit from:}

- fast, convenient online submission

- thorough peer review by experienced researchers in your field

- rapid publication on acceptance

- support for research data, including large and complex data types

- gold Open Access which fosters wider collaboration and increased citations

- maximum visibility for your research: over $100 \mathrm{M}$ website views per year

At BMC, research is always in progress.

Learn more biomedcentral.com/submissions 